\title{
PENERAPAN STRATEGI PEMBELAJARAN MOTIVASIONAL DENGAN PERMAINAN KARTU BERTEMA PROTISTA PADA SISWA KELAS X SMA
}

\author{
Ernita Rahmaniati \\ SMA Negeri 4 Pontianak \\ Email : errahmaniati@gmail.com
}

\begin{abstract}
This research is motivated tendency in the field of biology shows that learning outcomes in protists material has not achieved the expected results. This is because teachers are more active than the students, so that the learning-oriented teacher (teacher-oriented) whereas passive during the learning of their students as well as the presentation of learning materials in the classroom is still conventional. This type of research is Classroom Action Research (PTK). Data taken using test instruments, observation sheet and test evaluation of learning outcomes is a means of collecting qualitative data processed. The results showed that by application of learning strategy discovery learning using protists themed card game can improve motivation and results of students of class X MIA1 SMA 4 Pontianak

Keywords : Motivation, learning outcomes, card game, Discovery Learning
\end{abstract}

Biologi merupakan mata pelajaran yang sering dianggap pelajaran yang membosankan karena materi yang dipelajari di kelas $\mathrm{X}$ lebih kompleks, banyak bahasa latin, serta banyak hapalannya. Sehingga terdapat kecendrungan siswa kurang tertarik dengan mata pelajaran Biologi. Disamping itu adanya istilahistilah dalam Bahasa Latin, juga menambah kesan sulitnya belajar Biologi. Akibatnya, kebanyakan siswa mengalami kesulitan dalam mempelajari materi Biologi. Kesulitan belajar ini berpengaruh langsung maupun tidak langsung terhadap minat dan motivasi belajar siswa serta sikap terhadap mata pelajaran Biologi. Akibatnya, guru mengalami banyak kesulitan untuk memusatkan perhatian siswa dalam proses pembelajaran. Di lain pihak ada kecendrungan bahan ajar atau lembar kerja siswa yang disampaikan dan digunakan guru tidak mampu menumbuh kembangkan minat dan motivasi siswa belajar biologi.

Siswa yang gagal dalam mencapai nilai ketuntasan yang ditetapkan oleh guru mata pelajaran lebih disebabkan oleh rendahnya motivasi belajar siswa itu sendiri, dimana banyak siswa yang mengantuk pada saat belajar atau sulit memusatkan perhatiannya pada pembelajaran di kelas. Hal ini juga disebabkan oleh kurang efektifnya strategi pembelajaran yang diterapkan oleh guru dalam pembelajaran biologi di dalam kelas. Akibat dari rendahnya motivasi belajar siswa menyebabkan rendahnya hasil belajar siswa kelas $\mathrm{X}$ MIA 1 SMAN 4 Pontianak tahun pelajaran 2013-2014 pada materi 
bahasan Protista masih sangat rendah dibandingkan dengan hasil belajar siswa kelas $\mathrm{X}$ MIA lainnya yang hanya mencapai nilai rata-rata kelas 55,39 atau sebanyak $34,21 \%$ siswa di kelas tersebut yang telah mencapai nilai ketuntasan 77 .

Setelah peneliti melakukan refleksi dari pembelajaran yang telah dilaksanakan, maka dapat disimpulkan bahwa metode yang digunakan peneliti dalam penyampaian materi di dalam kelas tidak bervariasi, sehingga tidak mampu menciptakan suasana belajar yang menyenangkan dan meningkatkan motivasi belajar yang akan mendukung peningkatan hasil belajar siswa di dalam kelas. Di samping itu pula peneliti belum memanfaatkan media pembelajaran dalam penyampaian materi.

Untuk memecahkan masalah pembelajaran yang demikian itu perlu diupayakan beberapa pengembangan strategi pembelajaran yang mengoptimalkan motivasi belajar siswa dalam rangka peningkatan hasil belajar siswa secara menyeluruh. Persoalan yang dihadapi guru di Indonesia dewasa ini bukan hanya terbatas pada upaya membuat pengajaran yang lebih menarik, tetapi juga bagaimana cara menanamkan motivasi belajar dan bekerja pada siswa. Sebab motivasi merupakan variabel penting yang menjembatani pengajaran dengan prestasi atau hasil belajar.

Upaya peneliti dalam mengatasi rendahnya motivasi dan hasil belajar siswa pada materi Protista yaitu dengan mencari model pembelajaran yang efektif dan menyenangkan. Salah satu alternatif yang dipillih peneliti untuk mengatasi kendala di atas adalah menerapkan strategi pembelajaran Discovery Learning dengan menggunakan permainan kartu biologi bertema Protista dalam proses pembembelajaran. Dengan harapan melalui pemebalajaran dengan menerapkan permainan kartu bertema Protista ini dapat membantu kesulitan-kesulitan siswa sehingga motivasi dan hasil belajar siswa dapat ditingkatkan.

Adapun tujuan dari penelitian tindakan kelas ini adalah (1) mengetahui dan menganalisis kegiatan setiap siklus dalam proses pembelajaran Biologi terkait penerapan strategi pembelajaran Discovery Learning dengan menggunakan permainan kartu bertema Protista di kelas X MIA1 SMA Negeri 4 Pontianak tahun pelajaran $2014 \quad-\quad 2015$; (2) memperoleh informasi ada tidaknya peningkatan motivasi belajar terkait penerapan strategi pembelajaran Discovery Learning dengan menggunakan permainan kartu bertema Protista dalam proses pembelajaran Biologi di kelas $\mathrm{X}$ MIA1 SMA Negeri 4 Pontianak tahun pelajaran 2014 - 2015; dan (3) memperoleh informasi ada tidaknya peningkatan hasil belajar siswa terkait penerapan strategi pembelajaran Discovery Learning dengan menggunakan permainan kartu bertema Protista dalam proses pembelajaran Biologi di kelas $\mathrm{X}$ MIA1 SMA Negeri 4 Pontianak tahun pelajaran $2014-2015$.

Belajar merupakan suatu proses perubahan yang dilakukan oleh seseorang atau individu, tidak hanya sekedar banyak atau sedikitnya pengetahuan yang dimiliki, namun juga melputi seluruh kemampuan 
yang dimilikinya. Belajar harus memungkinkan terjadinya perubahan yang merupakan buah dari pengalaman. Pendapat ini secara jelas memusatkan perhatian mengenai betapa pentingnya aktivitas dalam proses belajar seseorang atau individu.

Strategi

pembelajaran

Discovery Learning umumnya diartikan sebagai pembelajaran yang melibatkan siswa dalam melakukan halhal dan berpikir tentang hal-hal yang mereka lakukan serta mendorong siswa untuk berlatih mencari jawaban dari setiap permasalahan yang harus dipecahkan sehingga pembelajaran tidak hanya berpusat pada guru. Silberman (2007) menyatakan, salah satu cara yang dapat membuat pembelajaran tetap melekat dalam pikiran adalah dengan menemukan sendiri konsep materi serta mengalokasikan waktu untuk meninjau kembali materi yang telah dipelajari.

Dengan menggunakan

Discovery Learning ialah suatu cara mengajar yang melibatkan siswa dalam proses kegiatan mental melalui tukar pendapat, dengan diskusi, seminar,membaca sendiri dan mecoba sendiri. Discovery Learning adalah strategi pembelajaran yang dalam prosesnya siswa berusaha menemukan sendiri dan memahami konsep dan definisi materi pembelajaran. Strategi pembelajaran ini memajukan cara belajar aktif yang berorientasi pada proses, mengarah sendiri dan reflektif.

Motivasi belajar siswa dapat timbul karena faktor-faktor intrinsik (faktor-faktor dari dalam diri siswa), berupa hasrat dan keinginan berhasil dan dorongan kebutuhan belajar, serta harapan akan cita-cita. Sedangkan faktor ekstrinsiknya (faktor-faktor dari luar diri siswa) adalah adanya penghargaan, lingkungan belajar yang kondusif, dan kegiatan belajar yang menarik.Kedua faktor tersebut disebabkab oleh rangsangan tertentu, sehingga seseorang berkeinginan untuk mnelakukan aktivitas belajar yang lebih giat dan semangat.

Hakikat motivasi belajar Hamzah B. Uno (2013: 23), "adalah dorongan internal atau eksternal pada peserta didik-peserta didik yang sedang belajar untuk mengadakan perubahan tingkah laku, pada umumnya dengan beberapa indicator atau unsur yang mendukung", sehingga dapat disimpulkan bahwa motivasi belajar siswa merupakan faktor penentu keberhasilan siswa dalam mencapai tujuan dari pembelajarannya seperti peningkatan prestasi atau hasil belajar dalam proses pembelajaran yang dilakukannya.

Pengertian hasil belajar adalah hasil yang telah dicapai dari yang telah dilakukan, dikerjakan, dan sebagainya. Dalam kaitannya dengan belajar, hasil berarti penguasaan pengetahuan atau keterampilan yang dikembangkan oleh guru melalui mata pelajaran, yang lazimnya ditunjukan dengan nilai test atau angka nilai yang diberikan oleh guru. Jadi hasil bermakna pada keberhasilan seseorang dalam belajar atau dalam bekerja atau aktivitas lainnya. Hasil belajar erat hubungannya dengan tujuan belajar. Hasil belajar merupakan hasil yang diperoleh siswa setelah ia menerima suatu pengetahuan yang berupa angka (nilai). Jadi aktivitas siswa mempunyai peranan yang sangat 
penting dalam proses belajar mengajar, tanpa adanya aktivitas siswa maka proses belajar mengajar tidak akan berjalan dengan baik, akibatnya hasil belajar yang dicapai siswa rendah.

Bermain merupakan berbagai bentuk kegiatan yang menyenangkan yang memberikan kepuasan pada diri anak yang bersifat tidak serius, fleksibel dan bahan mainan terkandung kegiatan yang mendidik. Melalui bermain, anak memperoleh pembelajaran yang mencakup ranah kognitif, sosial emosi dan psikomotor. Selain itu melalui bermain anak dirangsang untuk berkembang secara umum baik perkembangan cara berpikir, emosi maupun sosial. Di samping itu jika ditinjau dari segi pendidikan, bermain merupakan suatu kegiatan yang memberi peluang kepada anak untuk berkarya, melakukan dan menciptakan sesuatu dari permainan itu dengan tenaganya sendiri, baik dilakukan di dalam maupun di luar ruangan (Andang Ismail, 2006:24).

Permainan menurut Arif S. Sadiman (1996: 77) adalah setiap kontes antara pemain yang berinteraksi satu sama lain dengan mengikuti aturan-aturan tertentu untuk mencapai tujuan tertentu pula. Dalam setiap permainan mesti memiliki empat kompenen utama, yaitu: (a) adanya pemain; (b) adanya lingkungan di mana pemain berinteraksi; (c) adanya aturan main dan; (d) adanya tujuan yang akan dicapai, sedangkan kata "kartu" menurut kamus besar Bahasa Indonesia adalah kertas tebal yang tidak seberapa besar, biasanya berbentuk persegi panjang. Kartu merupakan salah satu media pembelajaran agar mempermudah dan memperjelas penyampaian materi pembelajaran atau ide (Poerwadarminta, 2006:524), sehingga yang dimaksud dengan permainan kartu di sini adalah kartu pertanyaan, di mana di dalam kartu ini terdapat pertanyaan yang menyangkut materi bahasan yang disampaikan khususnya materi Protista yang divariasikan dengan gambar yang berhubungan dengan materi yang disampaikan selama proses pembelajaran berlangsung.

\section{METODE}

Subyek dalam penelitian tindakan kelas ini adalah siswa kelas $\mathrm{X}$ MIA1 semester ganjil di SMAN 4 Pontianak tahun 2014/2015 dengan jumlah siswa yaitu 38 orang, terdiri dari 21 siswa perempuan dan 16 siswa laki-laki. Penelitian tindakan kelas adalah suatu penelitian yang digunakan secara sistematis reflektif terhadap berbagai tindakan yang dilakukan oleh guru sekaligus sebagai peneliti. Penelitian ini dimulai dengan menyusun perencanaan sampai penilaian terhadap tindakan nyata di dalam kelas berupa kegiatan belajarmengajar, hal ini diharapkan tidak ada lagi permasalahan yang menjadi kendala di dalam pembelajaran.

Penelitian tindakan kelas ini sangat diharapkan dapat bermanfaat bagi guru dalam rangka peningkatan hasil belajar di kelas, serta sebagai solusi dari masalah di kelas. Bentuk penelitian yang digunakan pada penelitian ini adalah penelitian tindakan kelas model Kurt Lewin. Kurt Lewin terdiri dari empat komponen, yaitu: perencanaan (planning), tindakan (acting), 
pengamatan (observing), dan refleksi (reflekting). Penelitian tindakan kelas ini dilaksanakan di SMA Negeri 4 Ponianak pada semester ganjil pada tahun pelajaran 2014 - 2015 mulai 15 Agustus s.d 25 Oktober 2014. Adapun tahapan-tahapam yang dilalui dalam penelitian tindakan ini adalah sebagai berikut:

1. Siklus I

\section{a. Perencanaan}

Pada tahap perencanaan ini dilakukan kegiatan-kegiatan sebegai berikut : (1) Penyusunan RPP dengan menerapka strategi pembelajaran yang digunakan dalam PTK ini; (2) Penyusunan kartu bertema Protista dan lembar masalah/ lembar kerja siswa sesuai dengan indikator pembelajaran yang akan dicapai;(3) Membuat instrumen pengamatan moivasi belajar siswa dan soal test yang akan diadakan untuk mengetahui hasil pembelajaran di kelas; (4) membentuk kelompok kerja siswa yang bersifat heterogen; memberikan penjelasan pada siswa tentang teknik pelaksanaan pembelajaran dengan menerapkan strategi pembelajaran dan media pembelajaran yang digunakan.

b. Pelaksanaan

Pada tahap pelaksanaan tindakan dilakuka proses pembelajaran sesuai dengan desain tindakan yaitu penerapan strategi pembelajaran Discovery Learning dengan menggunakan permainan kartu bertema Protista dengan langkah-langkah berikut ini : (1) Stimulatiom/pemberian

rangsangan; pada tahap ini siswa dihadapkan pada sesuatu yang menimbulkan kebingungannya, kemudian dilanjutkan untuk tidak memberi generalisasi, agar timbul keinginan untuk menyelidiki sendiri. Disamping itu guru dapat memulai kegiatan pembelajaran dengan mengajukan pertanyaan, anjuran membaca buku, dan aktivitas belajar lainnya yang mengarah pada persiapan pemecahan masalah dengan menggunakan permainan kartu bertema. (2) Problem statement/ identifikasi masalah, memberikan kesempatan pada siswa untuk mengidentifikasi dan menganalisis permasalahan yang mereka hadapi yang relevan dengan materi pembelajaran saat pembelajaran berlangsung. (3) Data collection / pengumpulan data; siswa bersama kelompoknya mengumpulkan informasi atau data untuk memecahkan masalah yang dihadapi dengan menggunakan permainan kartu bertema. (4) Data processing / pengolahan data; siswa bersama kelompoknya mengolah data yang telah dikumpulkan dari hasil permainan kartu bertema dimana data yang dikumpulkan tersebut diklasifikasi guna pembuktian lebih lanjut.(5) Verification (pembuktian); pada tahap ini siswa dan kelompoknya melakukan pemeriksaan secara cermat untuk mendukung benar atau tidaknya hipotesis yang dibuat tadi dengan didukung referensi atau sumber belajar yang relevan. (6) Generalization / menarik kesimpulan, merupaka proses menarik sebuah kesimpulan yang dapat dijadikan prinsip umum dan berlaku untuk semua kejadian atau masalah yang sama dengan memperhatikan hasil verifikasi. 
c. Observasi

Observasi atau pengamatan terhadap proses pelaksanaan tindakan kelas dilakukan oleh kolaborator, baik menggunakan instrumen observasi yang telah disediakan maupun secara langsung mencatat setiap kejadian yang teramati selama proses pembelajaran. Hasil observasi direkam dan didokumentasikan sebagai data penelitian.

d. Refleksi

Pada akhir setiap siklus tindakan, diadakan refleksi terhadap proses pembelajaran, berdasarkan data observasi , data hasil wawancara dan data pada jurnal harian siswa. Sedangkan data penilaian siswa berasal dari nilai kegiatan permainan kartu bertema dan nilai ulangan harian siswa. Dengan hasil refleksi ini peneliti dapat melihat apakah tindakan yang dilakukan dalam penelitian ini dapat meningkatkan efektifitas proses pembelajaran yang secara berkelanjutan akan meningkatkan pula prestasi belajar siswa.

2. Siklus II

Tindakan pada siklus II dilaksanakan berdasarkan temuantemuan hasil refleksi siklus I. Karena karakteristik materi hampir sama dan model pembelajaran yang sama, maka tahapan-tahapan penelitian tindakan kelas yang dilakukan tetap sama namun dengan berbagai perbaikan.

a. Perencanaan

Berdasarkan temuan pada tindakan siklus I, pada tahap perencanaan siklus II dilakukan berbagai persiapan seperti (1) identifikasi permasalahan yang ada selama siklus I berlangsung yaitu mengatasi kekurangaktifan antar anggota kelompok baik dalam melakukan permainan kartu bertema dan diskusi kelompok. Dengan demikian perencanaan tindakan suklus II diawali dengan pembentukan kelompok baru berdasarkan masukan dari siswa , (2) menyusun instrumen penelitian berupa kisi-kisi serta soal ulangan harian. Sesuai materi siklus II.

b. Pelaksanaan

Berdasarkan temuan pada siklus I, diperoleh data bahwa nilai siswa untuk aspek psikomotorik masih belum maksimal. Sebagai upaya perbaikan, maka pada tindakan siklus II dilakukan hal sebagai berikut : (1) sebelum KBM dimulai diberikan beberapa penjelasan tentang strategi permainan kartu bertema dengan jelas dan benar, strategi mengumpulkan daa, menganalisis data dan menarik kesimpulan; (2) diinstruksikan kepada siswa, agar mempersiapkan semua bahanbahan pendukung terutama bahan verifikasi data sehingga pembelajaran menjadi efektif dan efisien.

c. Observasi

Pengamatan terhadap proses pelaksanaan tindakan kelas pada siklus II dilakukan oleh kolaborator, baik menggunakan instrumen observasi yang telah disediakan maupun secara langsung mencatat setiap kejadian yang teramati selama proses pembelajaran. Hasil observasi direkam dan didokumentasikan sebagai data penelitian. 


\section{d. Refleksi}

Pada akhir siklus II, diadakan refleksi terhadap proses pembelajaran, berdasarkan data observasi, data hasil wawancara dan data pada jurnal harian siswa. Sedangkan data penilaian siswa berasal dari nilai proses permainan kartu bertema dan nilai ulangan harian siswa. Dengan hasil refleksi ini peneliti dapat melihat apakah tindakan yang dilakukan dalam siklus II ini dapat mengatasi permasalahan yang ditemukan selama pelaksanaan tindakan siklus I serta melihat apakah hasil belajar siswa pada siklus II sudah mencapai indikator kertercapaian yang ditentukan. Jika pada siklus II telah mencapai indikator ketercapaian yang ditetapkan maka penelitian tindakan kelas ini tidak dilanjutkan lagi pada siklus III.

Analisis dan pengolahan data yang digunakan peneliti dalam penelitian ini adalah teknik kuantitatif dan kualitatif. Hasil kegiatan observasi dan hasil wawancara akan memberikan gambaran mengenai kesulitan yang dialami guru dan siswa dalam pembelajaran. Temuan tersebut diharapkan sebagai gambaran dalam menemukan solusi terhadap kesulitan pembelajaran, agar guru dapat menerapkan strategi pembelajaran Discovery Learning dengan menggunakan permainan kartu bertema Protista dalam pembelajaran di dalam kelas, sehingga terjadi peningkatan motivasi dan hasil belajar siswa dalam pembelajaran biologi.

\section{HASIL DAN PEMBAHASAN}

Hasil penelitian tindakan kelas yang dilakukan pada kelas X MIA1
SMA Negeri 4 Pontianak ahun pelajaran 2014-2015 menunjukkan bahwa penerapan strategi pembelajaran Discovery Learning dengan menggunakan permainan kartu bertema dapat meningkatkan motivasi dan hasil belajar siswa dalam pembelajaran biologi materi Protista. Adapun peningkatan motivasi dan hasil belajar siswa dengan penerapan strategi pembelajaran Discovery Learning dengan menggunakan permainan kartu bertema ini meliputi:

1. Siklus I

Perencanaan pembelajaran pada siklus I dimulai dari guru bersama observer menyusun lembar observasi dan instrumen penilaian. Siklus ini terdiri dari 4 tahapan yang diuraikan sebagai berikut:

Tahapan perencanaan

pembelajaran pada siklus I dilaksanakan pada tanggal 20 September 2014 antara peneliti dengan Bapak Ibnu Thalib sebagai kolaborator dalam penelitian ini mengenai penggunaan permainan kartu bertema Protista. Dalam pertemuan ini dihasilkan rencana pembelajaran yang sesuai dengan materi, pendekatan dan model pembelajaran yang digunakan saat proses pembelajaran berlangsung. Kegiatan yang dilakukan dalam tahap perencanaan adalah sebagai berikut:

a. Guru mempelajari silabus yang berisikan kompetensi inti dan kompetensi dasar

b. Membuat skenario pembelajaran dengan menggunakan kartu bertema Protista.

c. Mempersiapkan perangkat pembelajaran 
d. Membuat instrumen observasi yang akan digunakan dalam mengobservasi kegiatan pembelajaran dengan menggunakan permainan kartu bertema Protista.

e. Merancang instrumen penilaian untuk menilai hasil belajar siswa setelah pembelajaran dengan menggunakan permainan kartu bertema Protista.
Pada siklus I perencanaan pembelajaran dilaksanakan dalam dua kali pertemuan yaitu pertemuan pertama dilaksanakan pada 22 September 2014 dan pertemuan kedua pada tanggal 29 September 2014.

Hasil pengamatan tentang motivasi belajar dan hasil belajar siswa pada siklus I dapat dilihat pada Tabel 1.

Tabel 1. Persentase motivasi belajar siswa dalam permainan kartu bertema protista siklus I.

\begin{tabular}{clccc}
\hline No & Kriteria Penilaian Sikap & Frekuensi & Persentase & Kategori \\
\hline 1 & Amat Baik & 0 & 0 & $\mathrm{~A}$ \\
\hline 2 & Baik & 18 & 47,37 & $\mathrm{~B}$ \\
\hline 3 & Cukup & 20 & 52,63 & $\mathrm{C}$ \\
\hline 4 & Kurang & 0 & 0 & $\mathrm{D}$ \\
\hline 5 & Kurang Sekali & 0 & 0 & $\mathrm{E}$ \\
\hline
\end{tabular}

Tabel 2. Persentase hasil belajar siswa dalam permainan kartu bertema protista siklus I.

\begin{tabular}{rlc}
\hline No & \multicolumn{1}{c}{ Kategori } & Persentase \\
\hline 1 & Rata-rata kelas & 69,65 \\
\hline 2 & Ketuntasan Klasikal & 55,26 \\
\hline 3 & Ketidaktuntasan Klasikal & 44,74 \\
\hline
\end{tabular}

Dari data di atas diketahui bahwa dalam pelaksanaan siklus I ini masih belum memenuhi kriteria baik, karena guru belum runut dalam menyampaikan pembelajaran. Langkah-langkah pembelajaran yang telah disusun dalam rencana pembelajaran belum dilaksanakan dengan baik oleh guru dan siswa. Dari hasil belajar siswa pada siklus I dapat dikatakan bahwa hasil belajar siswa terjadi peningkatan jika dibandingkan dengan hasil belajar siswa dari pra siklus, di mana hasil pra siklus adalah sebesar 14,26 atau $21,05 \%$ atau siswa yang tuntas pada pra siklus hanya sebanyak 13 siswa menjadi 21 siswa yang tuntas di siklus I.

2. Siklus II

Siklus II dilaksanakan berdasarkan refleksi pada siklus I yang belum mencapai indikator pencapaian dengan pelaksanaan siklus II sebagai berikut: Perencanaan siklus II dilaksanakan pada tanggal 01 Oktober 2014 dilakukan antara 
peneliti dan kolaborator. Pertemuan ini menghasilkan rencana pembelajaran yang dari konten isi disesuaikan hasil siklus I. Dalam perencanaan siklus II dilaksanakan sebanyak dua kali pertemuan, pertemuan pertama dilakukan pada tanggal 06 Oktober 2014 dan pertemuan kedua pada tanggal 13
Oktober 2014. Peningkatan motivasi dan hasil belajar diperoleh dari penerapan model pembelajaran motivasional dengan cara permainan kartu bertema Protista yang diterapkan pada kelas X MIA 1 pada siklus II dapat dilihat pada tabel hasil belajar berikut ini:

Tabel 3. Persentase motivasi belajar siswa dalam permainan kartu bertema protista siklus II.

\begin{tabular}{clccc}
\hline No & Kriteria Penilaian Sikap & Frekuensi & Persentase & Kategori \\
\hline 1 & Amat Baik & 19 & 50,00 & $\mathrm{~A}$ \\
\hline 2 & Baik & 10 & 26,32 & $\mathrm{~B}$ \\
\hline 3 & Cukup & 9 & 23,68 & $\mathrm{C}$ \\
\hline 4 & Kurang & 0 & 0 & $\mathrm{D}$ \\
5 & Kurang Sekali & 0 & 0 & $\mathrm{E}$ \\
\hline
\end{tabular}

Tabel 4. Persentase hasil belajar siswa dalam permainan kartu bertema protista siklus II.

\begin{tabular}{clc}
\hline No & \multicolumn{1}{c}{ Kategori } & Persentase \\
\hline 1 & Rata-rata kelas & 77,82 \\
\hline 2 & Ketuntasan Klasikal & 76,32 \\
\hline 3 & Ketidaktuntasan Klasikal & 23,68 \\
\hline
\end{tabular}

Pada siklus II nilai rata-rata kelas dan presentase ketuntasan terjadi peningkatan dari siklus I ke siklus II sebesar 8,17 untuk rata-rata kelas atau $18,42 \%$ atau jumlah siswa yang tuntas di siklus I sebanyak 21 siswa meningkat menjadi 29 siswa yang tuntas di siklus II.

Berdasarkan hasil penelitian yang dilakukan selama proses permainan, siswa merasa nyaman dengan pembelajaran menggunakan permainan kartu. Hal tersebut dibuktikan dengan adanya kekompakan dengan kelompoknya untuk membagi tugas dalam melakukan permainan, yaitu dalam satu kelompok bermain ada yang bertugas dalam mengemukakan pertanyaan, ada yang bertugas dalam menjawab pertanyaan, berpendapat dan mencatat hasil diskusi. Dalam permainan tersebut siswa nampak senang yaitu terlihat dari wajah siswa. Walaupun siswa merasa senang dengan permainan tersebut tetapi siswa tetap fokus dengan materi yang ada dalam kartu pertanyaan. Terlihat dari antusias siswa untuk menjawab pertanyaan tersebut.

Dengan belajar sambil bermain siswa dirangsang kemampuannya untuk berkembang secara umum, baik perkembangan berfikir, emosi maupun sosialnya. Sehingga siswa pada kelas X MIA 1 rata-rata hasil 
belajarnya dapat meningkat karena siswa dalam proses belajar mengajar merasa nyaman, senang dalam menerima materi dan tidak hanya mendengarkan ceramah dari guru. Selain faktor kenyamanan siswa dalam menerima materi dengan menggunakan permainan kartu, meningkatnya hasil belajar siswa dipengaruhi oleh faktor internal (faktor dari dalam) yang meliputi: kesehatan siswa, perhatian, minat, motivasi, kesiapan dan kematangan siswa dalam belajar dan menerima materi.

Hasil penelitian ini juga didukung dengan hasil wawancara yang dilakukan pada 5 orang siswa perwakilan dari kelas yang diberikan perlakuan yaitu kelas X MIA 1 yang dapat disimpulkan bahwa:

1. Mengganti model pembelajaran yang lama dengan model pembelajaran motivasional seperti pembelajaran dengan menggunakan permainan kartu bertema ini,siswa lebih aktif dan antusias serta termotivasi untuk belajar biologi yang selama ini dianggap membosankan.

2. Dengan menggunakan permainan kartu bertema ini, tingkat kejenuhan siswa dalam pembelajaran biologi di dalam kelas menjadi berkurang karena siswa merasa tertantang dalam memecahkan masalah atau menjawab pertanyaan-pertanyaan yang diajukan oleh teman-teman sesama siswa ataupun pertanyaan dari guru.

3. Dengan permainan kartu bertema ini, penyampaian materi pembelajara ini lebih meningkatkan keyakinan diri pada siswa dalam belajar seperti dalam mengemukakan pendapat dan mempertahankan argumen yang disampaikan oleh siswa pada saat pembelajaran berlangsung.

4. Pembelajaran materi Protista yang menerapkan strategi pembelajaran Discovery Learning dengan menggunakan permainan kartu bertema ini, siswa merasa puas dalam pembelajaran yang berlangsung karena pada saat pembelajaran berlangsung guru mengakui eksistensi siswa dan guru selalu memberikan penghargaan positif terhadap usaha siswa dalam menyelesaikan tugas mereka atau berhasil menjawab dengan tepat setiap pertanyaan yang diajukan guru maupun teman-teman sesama siswa.

Menurut Suyatno (2009) bahwa keberhasilan proses pembelajaran tidak terlepas dari kemampuan guru mengembangkan strategi pembelajaran yang berorientasi pada peningkatan motivasi dan hasil belajar siswa serta intensitas keterlibatan siswa secara aktif di dalam proses pembelajaran. Penerapan strategi pembelajaran merupakan keputusan mutlak yang dimiliki guru dalam bertindak pada proses pembelajaran dilaksanakan dengan menggunakan kecakapan dan sumber daya pendidikan yang tersedia untuk mencapai tujuan kompetensi yang ingin dicapai dalam pembelajaran itu sendiri. Strategi pembelajaran merupakan garis besar haluan guru dalam bertindak dan mengelola proses pembelajaran untuk mencapai tujuan pembelajaran secara efektif dan efisien.

Dari hasil penelitian yang telah dilakukan dengan mengembangkan 
strategi pembelajaran motivasional di dalam pembelajaran biologi, yang salah satunya penerapan strategi pembelajaran Discovery learning dengan menggunakan permainan kartu bertema Protista ini didapatkan bahwa terjadi peningkatan motivasi belajar dan hasil belajar siswa di kelas $X$ MIA. Dengan kata lain peningkatan perhatian, tingkat percaya diri, rasa puas dan merasakan adanya relevansi antara materi Protista dengan kehidupan sehari-hari, setelah menerapkan permainan kartu bertema Protista dalam pembelajaran sebagai salah satu model pembelajaran motivasional di dalam kelas. Hal ini disebabkan pemilihan model pembelajaran ini didasarkan pada karakteristik dan kebutuhan belajar siswa dan kondisi lingkungan serta tujuan yang akan dicapai dalam pembelajaran.

\section{SIMPULAN DAN SARAN}

Berdasarkan penelitian tindakan kelas ini dapat diambil simpulan sebagai berikut:

1. Penerapan strategi pembelajaran Discovery Learning dengan menggunakan permainan kartu bertema dapat meningkatkan motivasi belajar siswa dalam pembelajaran biologi materi Protista.

2. Penerapan strategi pembelajaran Discovery Learning dengan menggunakan permainan kartu bertema dapat meningkatkan hasil belajar siswa dalam pembelajaran biologi materi Protista.

Sehubungan dengan hasil penelitian tindakan kelas yang penulis lakukan, kiranya dapat memberikan saran sebagai berikut:

1. Bagi pendidik
Pendidik hendaknya dapat memilih model dan metode pembelajaran yang cocok untuk dipakai dalam menyampaikan materi pelajaran yang diampunya. Selain itu saat memakai atau menerapkan permainan kartu atau yang lainnya, seyogyanya guru betul-betul paham mengenai prosedur penerapannya, sehingga tujuan dari pembelajaran dapat tercapai secara optimal.

2. Bagi Siswa

Siswa hendaknya paham dan mengerti tujuan dari diterapkannya permainan kartu dalam pembelajaran biologi yaitu untuk belajar sambil bermain. Belajar sambil bermain akan dapat menciptakan suasana pembelajaran yang menyenangkan. Selain itu siswa diajak untuk bekerja sama (belajar bersama) dengan kelompoknya. Dengan ini diharapkan siswa dapat terus melaksanakan kewajibannya untuk belajar dan mampu meningkatkan motivasi dan hasil belajarnya dengan maksimal

\section{DAFTAR PUSTAKA}

Ismail, Andang. (2006). "Education Games Menjadi Cerdas dan Ceria dengan Permainan Edukatif', Yogyakarta : Pilar Media.

Poerwadarminta, W.J.S. (2006). Kamus Umum Bahasa Indonesia. Jakarta: Balai Pustaka

Sadiman, Arief S. dkk. (2008). Media Pendidikan: Pengertian, Pengembangan, dan Pemanfaatannya. Jakarta: PT Raja Grafindo Persada.

Silberman, Melvin L. (2007). Active Learning: $101 \quad$ Strategi 
12 Jurnal Pendidikan Matematika dan IPA Vol. 7 No. 2 Juli 2016: 1-12

Pembelajaran Aktif. Suyatno. (2009). Menjelajah Yogyakarta: YAPPENDIS. Pembelajaran Inovatif.

Sudrajat, Akhmad. (2010). Media Sidoarjo: Masmedia Buana Pembelajaran Berbasis Pustaka.

Komputer. Diakses dari http://akhmadsudrajat.wordpre ss.com/2010/07/16/mediapembelajaran-berbasiskomputer.

Uno, B. Hamzah. (2010). Teori Motivasi dan Pengukurannya Analisis di Bidang Pendidikan. Jakarta: Bumi Aksara. 